

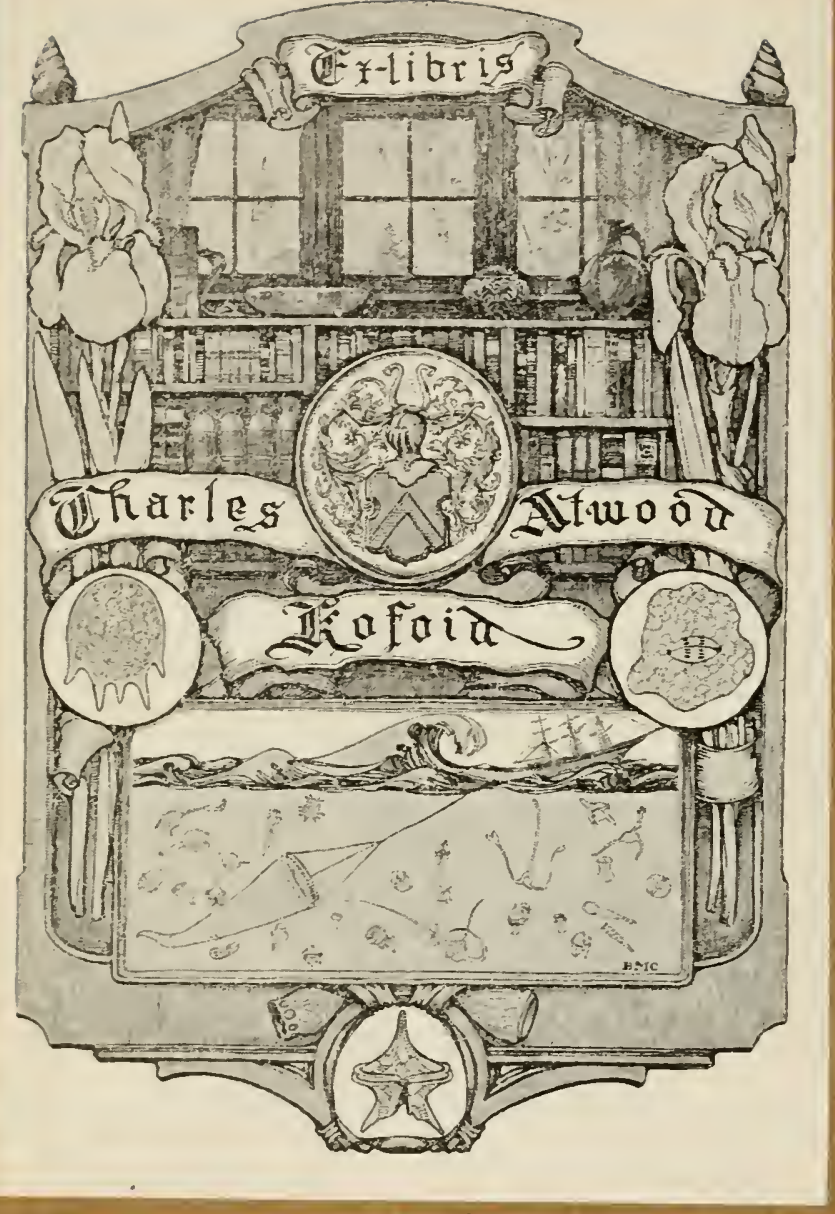


ONE SHILLINC T내동

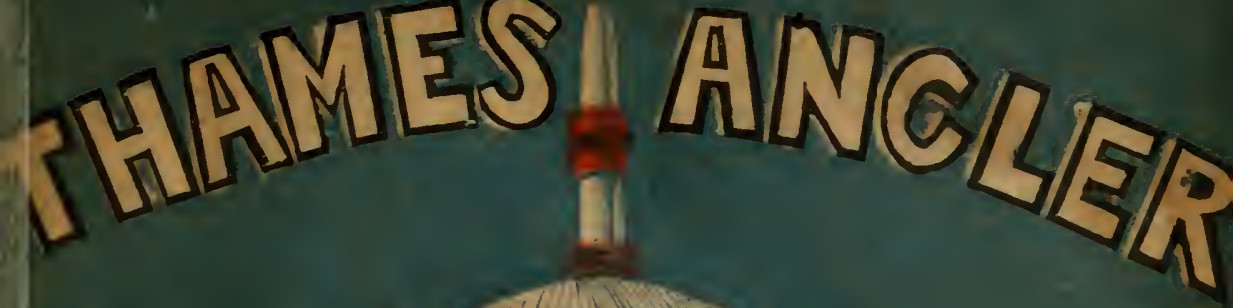

I

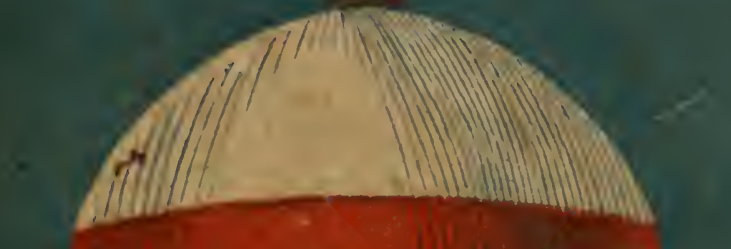

)

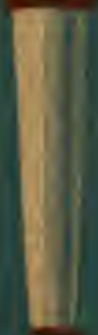

40 BY 


\title{
PARKINS AND GOTTO,
}

\section{$24 \& 25,0 X F O R D$ STREET.}

THE LARGEST STOCK IN EUROPE

\author{
$\mathrm{OF}$ \\ WRI'ITNG CASES, \\ D RESSING CASES,
}

TRAVELLING BAGS, INKSTANDS,

ENVELOPE CASES,

KNAPSACKS, PIC NIC CASES, BLOTTING BOOKS,

S T A T ION ER Y CABI N E T S,

PAPIER MACHE GOODS,

PEARL AND TORTOISESHELI, GOODS, DESPA'CH BOXES,

CASES OF CHOICE CUTIERY, \&C.

BIBLES, PRAYER BOOKS, \& CHURCH SERVICES. ILLUSTRATED BOOKS SENT POST FREE.

PARKINS AND GO'TTO, WRITING \& DRESSING GASE MAKERS,

24 \& 25, OXFORD STREET. 


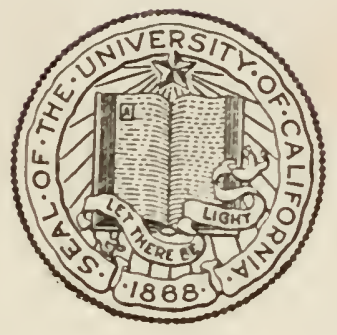

\section{THE LIBRARY}

OF

THE UNIVERSITY OF CALIFORNIA

PRESENTED BY

PROF. CHARLES A. KOFOID AND MRS. PRUDENCE W. KOFOID 


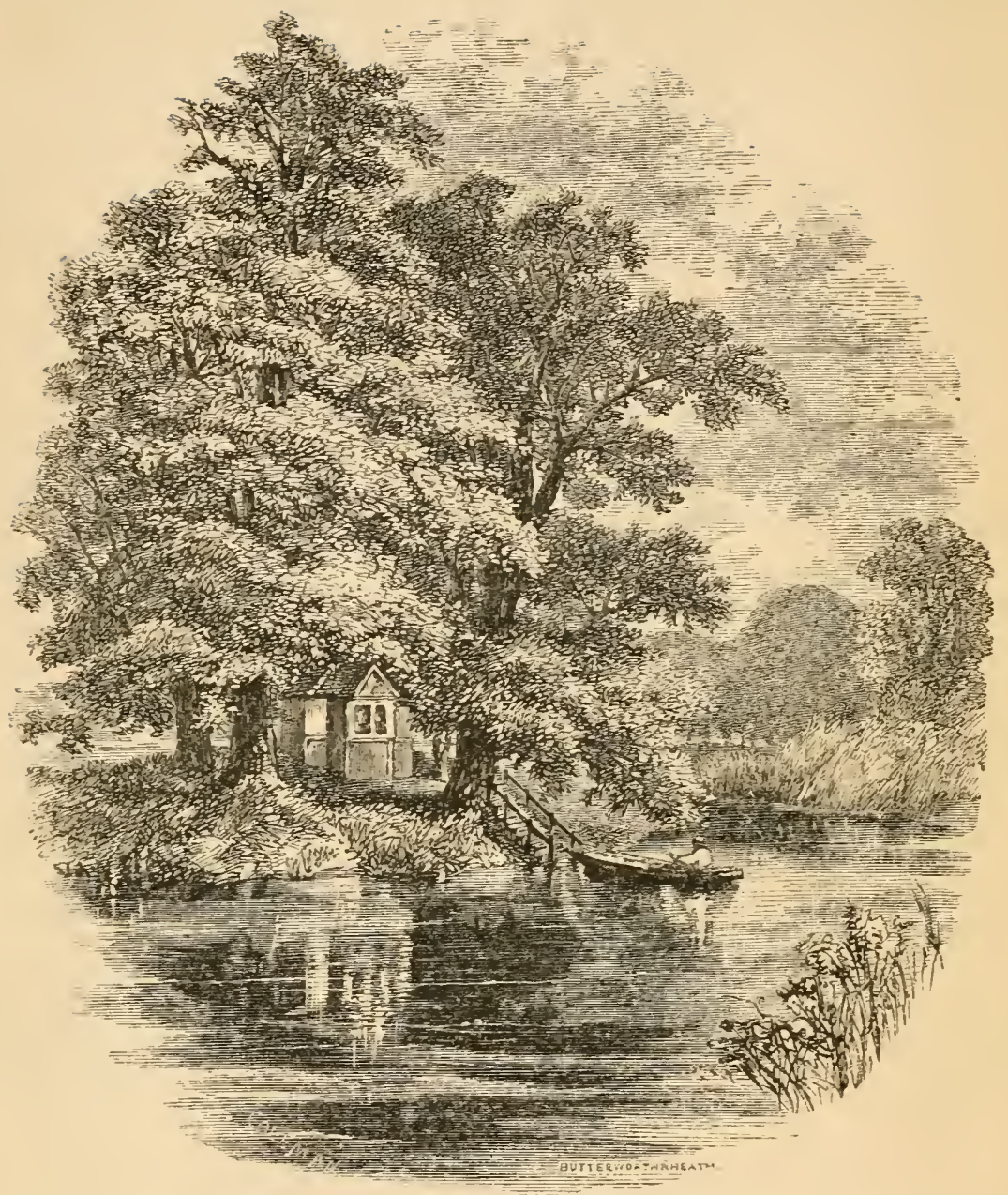

MAGNA CHARTA ISLAND, On the Thames, near Egliam. 


\section{THE}

THAMIE ANGLE琶。

\section{ARTHUR SMITH.}

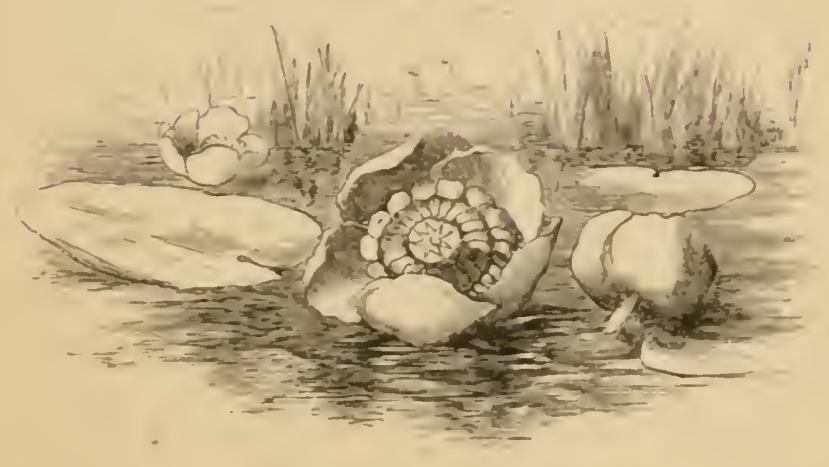

SECOND EDITION.

LONDON :

CHAPMAN AND HALL, 193, PICCADILLY. 



\title{
$5 H 605$ $\Sigma^{\prime} 65$ 1860
}

\section{RICHARD ARABIN, ESQ.,}

\author{
THE SECOND EDITION OF
}

C bुis âdittle 30ook

(WITH ALL ITS FAULTS)

IS DEDICATED,

BY HIS SIICERE FIIEND,

THE $\Lambda$ UTHOR. 
Digitized by the Internet Archive in 2008 with funding from Microsoft Corporation 


\section{THE THAMES ANGL䓪.}

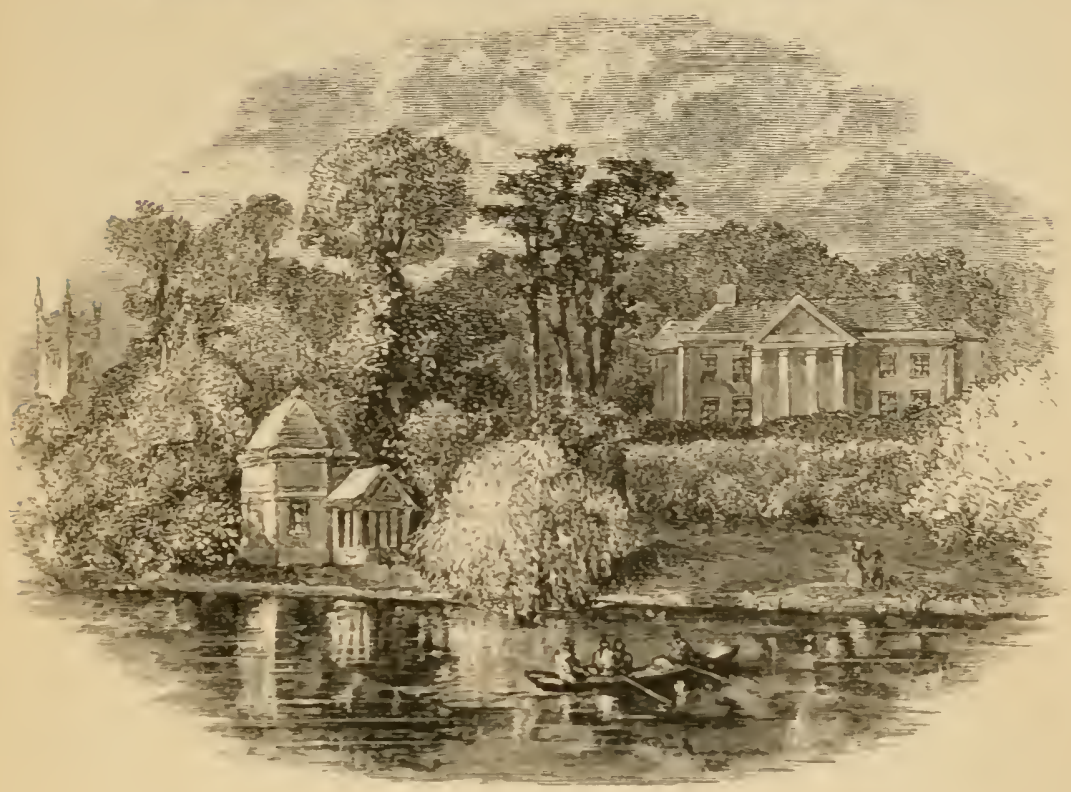

CHAPTER I.

A CONFEREJCE BETWEEX SMITH (COMMONLY CALLED PISCATOR), AN ANGLER ; BROWX, A TRAVFLIAR; JOAES, A WEALTHY PARTY; AND ROBLSON, A IIAN ABOLT TOWN; EACH COMNENDING HIS RECLEATION.

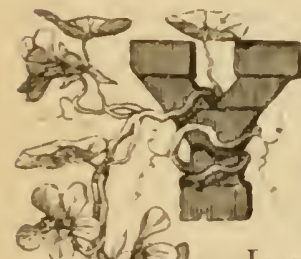

Piscator.

OU are well overtaken, gentlemen. A good morning to you. I have stretched my legs up the hill to Richmond Park, on my way to 'Teddington Lock, whither I am bound this delicious day.

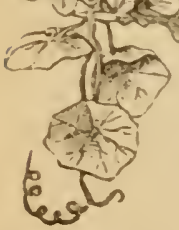

Joses. And I, sir, have come down here by the rail. I should tell you at the same time I have got a carriage (and as handsome a one as you could well see), which 1 gave 200 guineas for in Long Acre. But my wife and daughters are making morning calls to-day; so I came down by train to look at a little property hereabouts for sale. It may be had for a few 
thousands; and "a place on the river" is a respectable thing to have.

Robinson. And I, gentlemen, am waiting for a dinner party to arrive. Mademoiselle Pussi, who has made such a hit at the Opera in L'Amour Volage, is going to dine with us at the Star and Garter. The manager also brings down Nina Throstletini; and Grumbini, the bass; and La Grassière, the contralto. Young Witsend, the burlesque writer, who has done The Huguenots; or, Pop go the Protestants, now playing, will also be with us.

Joxes. I took the stage-box from Mr. Sams to see that the other night. Not so bad. Do you remember where he says, whilst Raoul is asleep-

"When he is up, on him we shall be down?"

Up and down-you see? Play on the words.

Robissox. Ha! ha! And when he sends the maid of honour for the drink he says-

"If she don't bring the liquor; lick her well."

First rate! We also expect Lord Spuffle; and young $\mathrm{Yaw}$, of the Guards, who drives them down in his drag; and Sir Harry Fogey.

Brows. I also expect a friend to dinner, and a foreignerMnnsieur Pastel, a young French artist, whom I met amongst the Alps last autumn. I have told him I will show him a view, and give him a dinner, equal to what he might enjoy at Philippe's, provided that restaurant was placed on the hill of St. Cloud instead of in the dingy Rue Montorgueil: and, therefore, we also shall go to the Star and Garter. But I hold it to be something of a risk to raunt an English dinner to a foreigner.

Jones. Money can command it, sir. Give Ellis, or Hart, or Quartermaine, or Lovegrove, their sum, and they can challenge the world for good feeding. But you must pay for it.

Robissox. Precisely. When Lord Chesterfield quitted his office of Master of the Buckhounds a dinner was given to him at the Clarendon. 'The eminent swell, Count d'Orsay, arew up the memu. The number was thirty, and the dinner six guineas a head; but it was pronounced by everybody a triumph of cookery.

Browr. (Reclioning). But it is one hundred and fifty-seren francs a head. Truly, a great deal! 
Joxes. I treated my family and the gorerness to a dinner when we were at Paris, at the what do you call it-the Three Provincial Brothers was the name.

Brows. You mean, I think, the Trois Frères Provençeaux. What did you pay?

Joxes. Forty-two franes a head; and I believed that was a topping price. But I thought the flounders poor-very poor, sir. No souchée.

Robresox. It is a Duteh and English dish; and we manage it to perfection. I am to-day looking forward to the flomnders.

Piscator. Nay: rather the perch, about here, I think.

Robinsox. Well, flounders or perch, the souche is equally good.

Piscator. I spoke of taking them.

Robinsox. So did I-with brown bread and butter-any quantity of brown bread and butter.

Joxes. Well, give me a cut of salmon at Christmas, when it's five shillings a pound, with a cucumber at half-a-guinea. That is my notion of fish. Any poor devil can eat it when it is cheap. There is no fish like salmon.

Browx. For my part I believe the cheap domestic sole is as fine a fish as swims. Te do not care about it because it costs nothing. But it is excellent fried ; and it is one of the rery few points in which a private kitchen excels a tavern-to fry a sole well; for I dislike the manner of the tavern, sir, or eating-house, to send it up with its covering that all lifts off at once like a piece of greasy brown paper.

Robisson. It is equally good boiled, when fine, with shrimp sance; or broiled, with lemon and fresh butter, for breakfast.

Browx. Or take it en gratin, à la Normande, en filcts, à la Hollandaise-any how, what do you think, sir?

Piscator. For'sooth, the fish in which I do put most delight, is that which is the most difficult to take.

Joxes. Just so; as Whitebait in December.

Piscator. Pardon me, sir; I spolie as a lover of the rod.

Robissox. A pedagogue, perhaps-from Eton it may be-of the swish-tail slightly?

Piscator. Nay. Do you know Walton?

JoNEs. I do: rather. 'There is an hotel at Oatlands adjoining, used by the quality. My family stay there when we are painting our house in 'Tyburnia. 
Piscator. It was Walton's Angler that I alluded to.

Joses. We tried him once. His name was Rogerson; he lives by the Ship Inn.

Piscator. It is the book, I mean. You will there find the joys of the angler's life well defined. It is indeed a great delight. I know of no pleasure like that which a day's sport affords.

Jones. It is lucky we differ in our tastes. A rise in the share market, I must confess, is my happiness.

Brows. And I, sir, think that waking first in the morning, in a continental hotel, with a bright tour before you, and arranging your day, with nothing to think about but idle enjoyment, is the perfection of life.

Robisson. Give me a stall at the Opera, out of the draught, or a pit box with one agreeable companion, a full house, and the curtain just rising for Trovatore or Fra Diavolo. What is equal to that supreme moment?

Prscator. Gadso! would not a seat in a punt on a wet day at the Barbel pitch under the second arch of

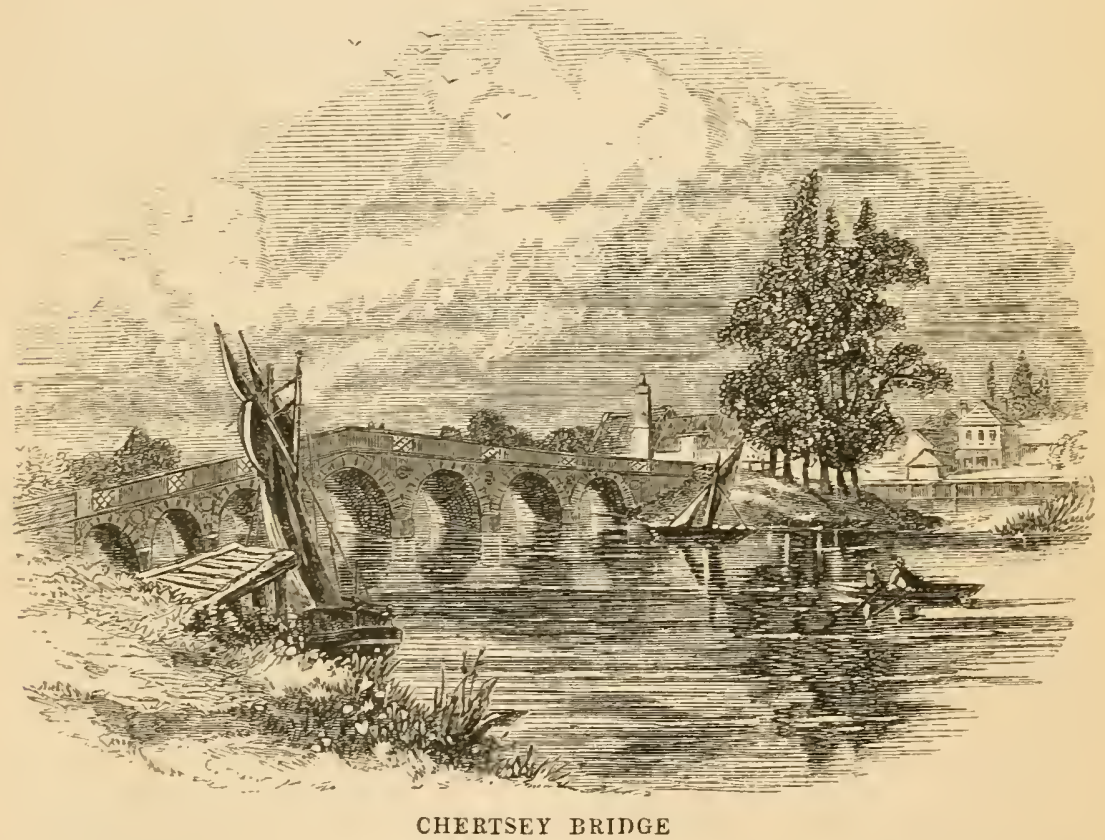

be better? Let us sit down on this soft dry turf, and look at 
that scene before us. Contemplate it, and tell me if the dingy office of a stockbroker, the salle-á-manger of a foreign hotel, or the best of Mr. Bererley's illustrations for Mr. Gye's management, can equal that:- and its enjoyment entails no risk, or expense, or disappointment.

[They sit down, and think a bit.

Robisson. A cider cup wouldn't be a bad thing, just now.

Brown. Or a cool bottle of hock.

Piscator. Or a tankard of home-brewed ale, which I do affect more than foreign wine.

Joxes. I have some port in my cellars that cost me fourteen guineas a dozen. 'That's what I call wine. I can give a friend as good a bottle of wine as-

Piscator. There! he has caught him, in that punt below-a roach that weiwhs a pound. See how he flaps upon the surface, and now is gently landed.

Robrssox. It is wonderful to see how men can find pleasure in such dull occupation. My friend, young Witsend, has written this lyric of an angler, which is to be sung by Mr. Robson, in the new burlesque. I have a copy, and it runs thus :-

\section{THE SONG OF THE UNSUCCESSFUL ANGLER.}

I cannot tell the reason, it is really rery odd,

My tackle is first-rate, and I're a most expensive rod-

Bonght at the Silver Troüt, the shop that's always selling off, And yet with all my outlay, l're got nothing but a cough.

I think the fish are altered since old Waltou wrote his book, They shun the simple gentle, and mistrust it "with a hook;" I think I mayn't be deep enough, in rain I move the quill, For fish as deeply as I choose, the fish are deeper still.

No Pike I've seen-the only one was that unpleasant wicket, Where threepence I was forced to pay, and now I've lost the ticket;

Nor yet a single Perch, for which my lucky stars to thank, Except the perch I're taken on this damp rheurnatic bank.

I can't pick up a Chub, though on the lock all day I stick, (They say it is impossible a lock of Chubb to pick);

A Flouncuer would be welcome, but uufeeling wags remark, I shall get lots of them to-night returuing in the dark.

Upon that bobbing quill all day I've nothing done but gloat, Till I've almost become one-as the song sars, "I'm a float!" Come Soles, Brill, Flounders, fresh or salt, however flat re be, Be sure you will not fail to tind a greater flat in me. 
Joxes. Very good! It is curious to see how these poor scribbling devils think of these things, for I believe the majority of them can hardly rub one shilling against another. My son is having an expensive education, with a clergyman for a private tutor, and the best rooms in college, but I doubt whether he could do that. I pay-

Piscator. Another fish ! That is, indeed, truly sport.

Browr. I can't make it out-it strikes me as stupid still. I can fancy pulling out trout from under the rock of the Handeck, in Switzerland-or netting the glittering anchovies on the blue rippling sea-side at Naples-or, surer and better, opening a fresh tin of sardines anywhere about the Mediterranean-or hanling in a black and lively lobster off Norway - to say nothing of pitching a flapping salmon on to the wild arbutus embers-

Robrssox. Or watching his "middle piece," as Mr. Rule opens a fresh kit from Aberdeen, in his really submarine repository in Maiden Lane. What piscatorial joy can equal that! (Robrsson becomes excited.) I see it now! The Opera is just over, and we pant for sustenance, having heard Dinorah, on a subscription night, for the hundred-and-ever-so-manyeth time-

JoNes. I gave eight guineas for a box to hear it on the night Her Majesty-

Brown. I heard it of old in Paris. It will never be popular. Can you recollect one air that anybody can whistle? - not one. They all talk about "The Shadow Dance," and nothing else;and what is "The Shadow Dance"-a very commonplace elaboration of part of the College Hornpipe. Do you, while it is going on, care one single pin about what becomes of anybody, anywhere, in any manner, all the way through? and when it is all orer, have you one recollection of any particular air lingering in your ear. No, no, a dull thing-a very dull thing indeed.

Robissow. That's just what I was coming to. It is over, and then, being in a craving state for refreshment, and unencumbered, you slip out alone through the crush, and are at Rule's in two minutes. That great philosophical triton, who rules as well the destinies of Gorgona and the natives of Burnham with his sway, is propounding an ethical theory to a chance but bewildered customer. The matronly and pleasant Amphitrite of his crustacean home is giring to the messenger the fresh and scarcely cold lobster at eighteen-pence; which anon, placed on the battered old knife-scored, semi-plated, copper-showing, roughly- 
indented "side-dish" of the Corent-garden Hotel, will be charged three-and-sixpence to the country visitor.

Brows. Truly, a vivid tableau of one of the "appointments" of a ghastly English hotel. Away with them-their thrummy carpets, hearse-like four-posters, lumbering side-boards, heary furniture, writing-table-and-sofa-less bed-rooms, six-shilling-abottle wine (even vin ordinaire, which they call "claret"), grim chop-and-fowl extent of the carte, gaunt entire "equipage" of coffee, and no demi-tasse, at two shillings instead of sixpence, separate fee for waiters, separate fee for chambermaid, separate fee for boots, separate fee for porter, separate fee for everybody hanging on, fluttering, obstructing, never-attending, musty, fusty, effete, conventional, regulation, world-run-by, hopeless nuisances, edncated, fostered, defended, supported, and irretrievably fussilized by hotel-keepers, who cling to their "old-established" way of conducting their business-as if it was an old-established coat, or a stage-coach journey, or a black draught, or a featherbed, or an egg, or a pork-pie, or anything else which age rendered worthless. Ah:

[Brow is quite overcome with his indignation.

Robussox. But lo! Rule to the rescue: Observe his three sons-those Rules without exception. The eldest has been accosted by a heedless passer-lyy, who on his way to the Cyderian caves has come in to asli for orsters-oysters in July: Robert -toi que jaime, for your attention-reproves him mildly: he says, "Why, you'll want to grow whellis in fern-cases next!" and the heedless passer-by retires quailed and reproved. The smaller sprite, Roulette, "has been labouring with chisel and hammer at the Aberdeen kit the whiles. It is opened, and can the world show a finer spectacle than those jowls, which'speak even now with a mild eloquence expressive of the delight they are about to give by their consumption! Observe how the liquor is taken up by the congenial scallop shell-how the sprig of femmel graces the dish-and how the small white loaf, the dewy pat of butter, the Bedford Head mild ale, and the domestic but essential pepper and vinegar, lend their aid to the consummation of delights--it is an intensity! To go to the Opera without pickled salmon at Rule's afterwards is Norma without Grisi, the Volunteers without their dress, claret-cup withont borage, a petticont without a hoop, a cab-stand without a Hansom, the ministry without Palmerston, or nothing without anything. 
[Robinson is also overcome with his delight. Jones is feeling sovereigns in his pocket, and can't find a remark to make.].

Piscator. You are brave gentlemen, each for your pleasure. I cannot define my own before such eloquence, but I will, an' it please you, win you over to my own joys. Let us make a compact. I will indoctrinate you into the art of home angling, if your leisure will permit. Sir (to JoNes), let me try if I cannot show you a pleasure which may rejoice you more than the outlay of a heavy sum may command, and with much health, content, and pleasant spirits to boot. (To Browr.) Let me to you, sir, offer a little relaxation, which, enjoyed in the open air, and in the calm summer-tide of England, may lure you for a few weeks from your continental peregrinations. (To Roвrssov.) And I will cause you, sir, to be so bitten with a new pleasure, that even your West-end delights shall fade before my quiet recreation and enjoyment. You must study what I am about to teach, and when you have tried it all, we will meet for some fried Gudgeon and a baked Pike, some ham and peas, and an apricot tart, at a Thames-side inn, and I hope you will not find me so great a fool as an angler is generally supposed to be. (PIscator advances to the brow of Richmond Hill, and addresses the world therefrom generally, as a "tag.") And if these kind friends will but smile upon our efforts, then shall we be able to say, in the words of rare Ben Jonson-

"Happy am I, in that I bought this book; Happy his studies who composed this book, And fortunate the man who sold this book."

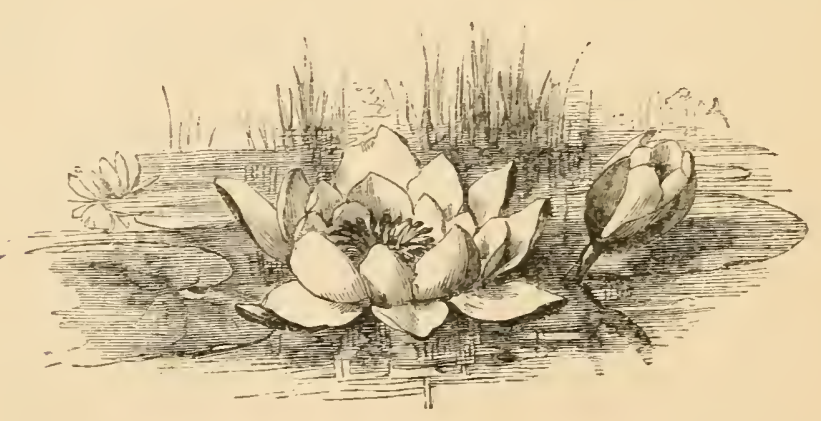




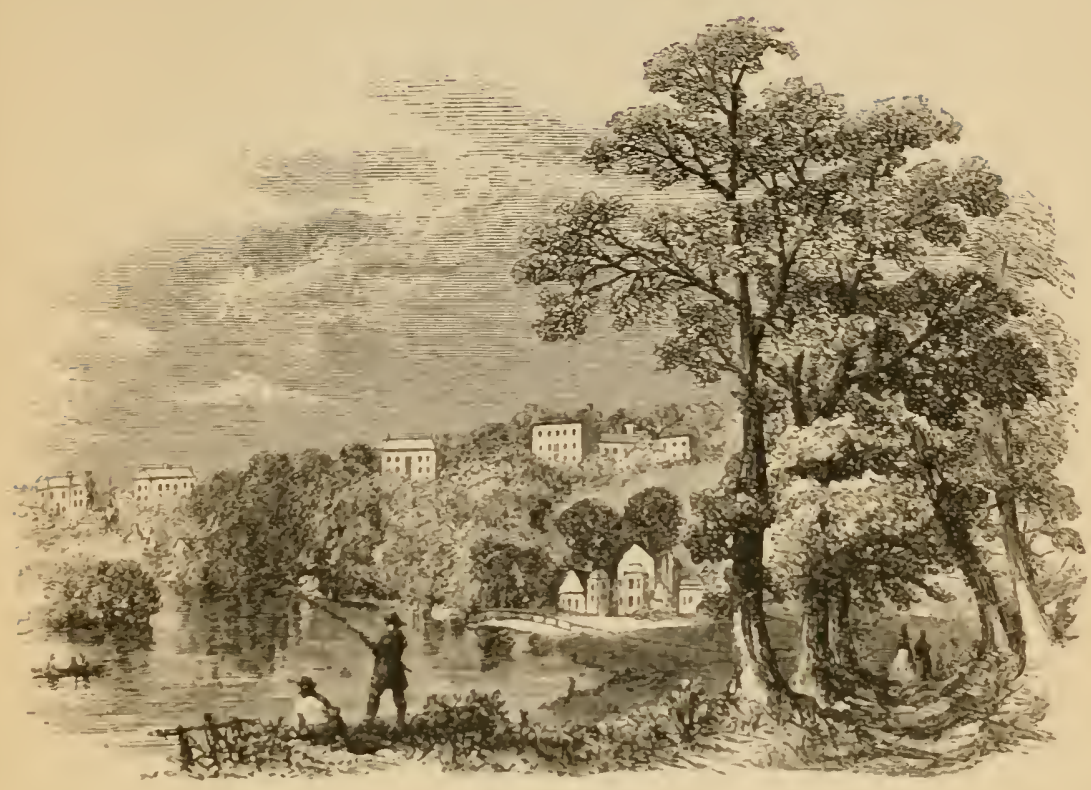

RICHMOND.

\section{CHA P T ER I I.}

\section{A SUMMER IDYLI.}

Young Robinson had fled the town, and sat Thcre on the hot hill-side by Twickeuham, Mopping, none near him save a little birdA sparrow, aged, and not to be entrapped With outer husks of corn: dead silence reigned Throughont the place, save that one little boy, 'The butcher's urchin, piping accents shrill, Expressed a wish that Sarah should aseend.

For hither had he fled, his canse of flight The weather; never had such direful heatSuch baking, burning, scorching, sultry heat Been known in town. On 'busses' knifeboards stretched The city clerks, all tongue-protruded, lay; Adown the actor's sweat-bedabbled cheek The bismuth ran; in Hungerford's gay halls The penny ice collapsed, and Sainsbury's 
Rang with the popping of self-shooting corks.

One, only one, amid the hive of men,

Could freely more-Buovo Core; he,

The famous Salamander of Cremorne.

There, on the hot hill-side, lay Robinson, His vest apart, his collar folded back,

Grass in his hair and worry in his head;

For, though he slept, no peaceful slumber soothed

His wearied brain, through which for ever ran

Sharp troublous dreams and visions of despair;

For, though his open mouth was full as dry

As wig of limeburner, or Tupper's odes,

$\mathrm{He}$, in his visions, sat in Grange's shop,

Around him mountains of ice-cream, while near

Stood Rumsey Foster, pointing to a cask

Of foaming Allsopp; in the background, ranged

Bin upon bin, long-necked and rellow-sealed,

Were flasks of choicest claret "duty free :"

But, ever as the dreamer stretched his arm

To grasp or ice, or beer, or claret cool,

The tempting viands faded from his sight,

And in their place rose thirst-exciting stores-

Bedevilled biscuits and anchory paste,

Which ou his poor parched palate but awoke

A fiercer flame, so that, enraged, he shrieked, And shrieking waked, and waking saw his friends,

Good Brown and Jones, who watched him in amaze.

Then out spoke Jones, "What is it, Robinson?"?

Just now as Brown and I strode up the hill,

Muttering each to the other of his thirst,

Of how the heat was not to be endured,

Of what we'd give but for one creaming pint

Of bitter beer, sudden a voice raug out,

Crying, 'To drink! to drink!' A pleasant smile

Streamed o'er the wrinkled face of honest Brown

As these words fell upon his ear, and straight

We hastened hither whence the accents came,

And found thee sleeping. Prythee now arise,

Give us this drink, and cool our coppers hot."

But Robinson declared that he bad nought, That he himself was parched, that his tongue clave

Unto his mouth for dryness; and they all

Sat down lamenting, weeping o'er their lot.

When by them marching came Piscator Smith;

Lightly he laughed when they their state described,

And drawing from his creel a leather tlask,

Big-bellied, swollen, holding near a quart,

"Be this," he cried, "the prize to him who best", 
Shall sing the praises of the drink he lores.

Try yon, first, Brown;" and Brown, thus pressed, began :-

"In punch, if pnnch be good, if punch be ours, Acid and sweet should be just equal powersExcess in one is ruin to it all.

"It is the little rind from off the fruit, Cut into thinnest slices by the 'cute, Which, ever moistening, slowly savours all.

"The little rind from off the lemon fruit, And distillation from the sweet cane's root, Which, ever moistening, slowly sarour all.

"It is not worth the keeping, let it go.

Craven is he who at such drink is slow;

Then quaff it not at all, or all in all."

"O Fisher! do you love my little rhyme?"

Piscator looked, and seemed inclined to yield, So unctuous was Brown's voice, so fat his face, But in a minute, "Jones," he said, "strike up!" Iluttering about bronchitis Jones commenced:-

"Beer, bitter becr-I know not what they meanBeer which they in some unknown depths prepare, Flies to the head and surges in the eyes. I'm looking on this claret-budget-bill, Aud thinking of the ales that are no more.

"Fresh as the globules glittering in the ale Some friendly pump, brings from the under world, Sad as the fate suspended over one Who sinks from too mucl salmon on the curb; So sad, so fresh, the ales that are no more."

"Now liobinson, take up the strain," Smith cried; But Robinson, a thorough dufier he, Trolled out some fecble song about King Cole, A silly monarch, always calling out For bowls and fiddlers. "Jolly sciul, forsooth! Though now some thirty summers I liave passed, But little fun in fiddlers I have found:

Show me a fiddler, I'll show you a fool," Thus Smith, irate. Then, "I will sing," he said, "One of old Izaak Walton's merry strains."

"Hey no nouny!

Mavis, incrle, and rosemary, Fling the line and sing with glee, Hey no nonuy! 
"The Swan at Dittou's bonny; They will cook rou in a crack Hallibut and stickleback, Of frying bream they have the knack. Hey no nonny!

"For Perch I off to Weybridge sneak, For Eels I try up any creek, All the year round once a week. Hey no nonny!"

He ceased, and from the others there arose Plaudits both loud and long; then clarnoured they Again for drink, but then the wily Smith, Judging that he had better sung than all, Placed to his lips the flask, drained the contents Down to the dregs-and all the land was glad.

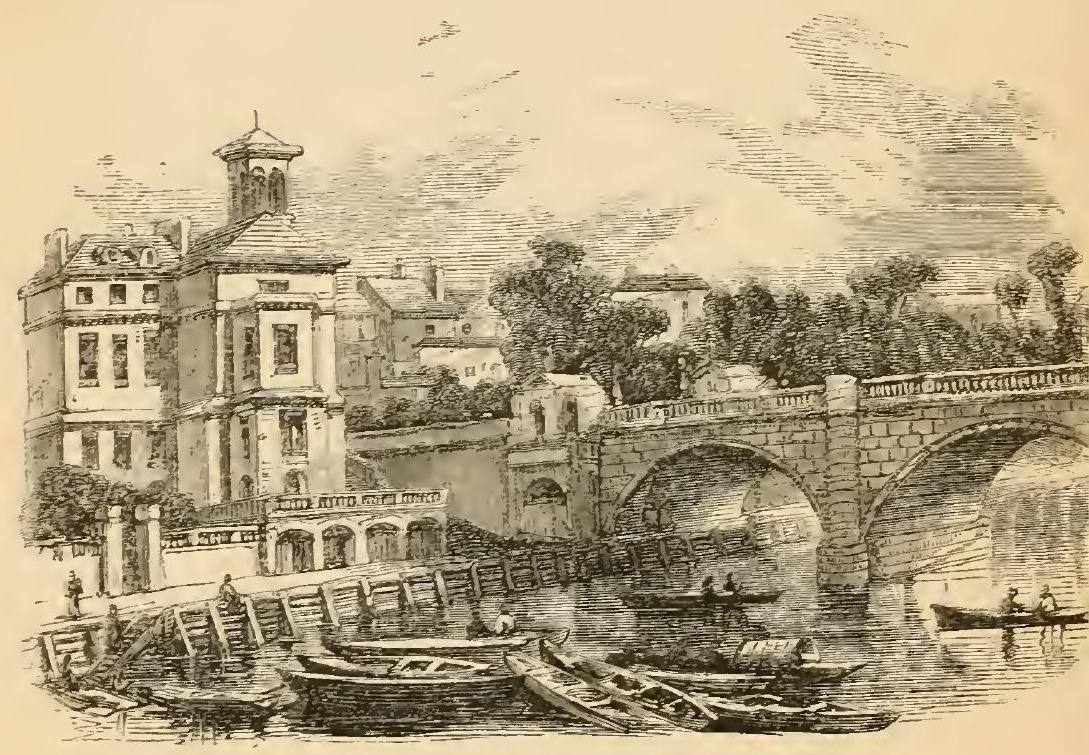

RICHMOND BRIDGE. 


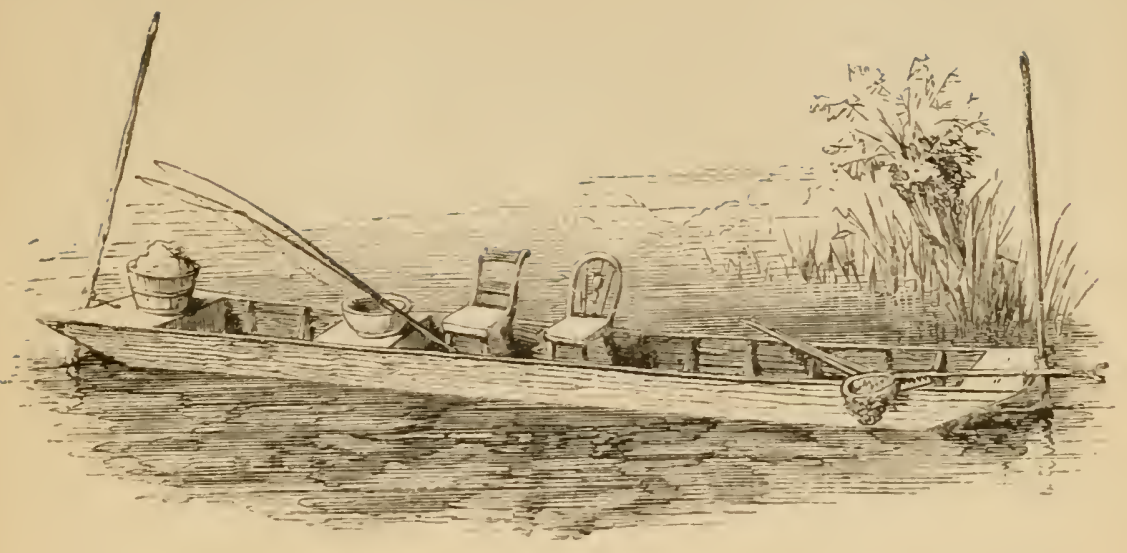

CHAPTER III.

OF THE MATERIALS FOR THAMES AFGLING.

In this chapter I propose to grive my readers, first, a list of materials used generally in Thames angling; and then, a full explanation of those articles which do not come under the description of tackle used for any particular fish, but are common to many linds of angling. And I would refer those of the public who may fancy that any article of tackle, or variety of bait, is forgotten in the list, to the title of this little book; and impress on them, that I confine myself entirely to the 'Thames and its tributaries, omitting all mention of salmon and trout streams, and the mode of fishing with a fly-the latter, from a consciousness that, though most of the small rivers and streams which empty themselves into the Thames are trout streams, there are so many excellent worlis on the subject of fly fishing (particularly Mr. Hofland's), as to render it a hopeless task to attempt any improvement on them. Having given these few lines of explanation, let me proceed to the list of articles required by a Thames angler:-

Rods for spinning and bottom fishing; ruming lines of light material for float fishing, and dressed lines for spinning and trolling; winders, or reels, for rumning lines; bottoms, of single hair and silk-worm gut, average length three to four yards; 
trolling hooks on wire or gimp, for the gorge; snap-hooks; gut spinning tackle; gimp and gut traces, with swivels; hooks tied on gimp, from Nos. 2 to 7 ; hooks tied on gut, from 2 to 12 ; ditto on hair, from 10 to 13 ; loose hooks; paternosters for perch fishing; floats of different sizes; leads for plumbing; ledgers, pateruosters, traces, and bullets with holes in them; split shot, and foat-cans; landing-net and gaff; clearing-ring, gentle-box, bran-bag and worm-bags; live-bait kettle; fishing book, fitted with a winder, pair of pliers, scissors, knife, disgorger, baitingneedle, India-rubber, cobblers' wax, sewing silk, string; basket; bait for the fish, and food for yourself.

Having now given a list of the angler's requisites, it will be necessary to speak of some of these articles in detail, and I will begin with

\section{RODS.}

I shall not adopt the conventional plan of instructing my readers at what season of the year they should enter a wood and cut the branches of the hickory, for the purpose of manufacturing their own rods; for, judging from the melancholy specimens that I have seen of amateur mechanism in this line, a rod thus produced, like most other things that are made at home, rould be a sorry competitor against one turned out by any of our fishingtackle manufactirers. I will tell the beginner what sort of rod he ought to purchase, and this will, of course, depend in a great measure on his means. If he can only afford one, this should be what is called a general rod, of four or five joints, having two butts, one very short for punt fishing, and the longer one bored to carry three or four top joints : of these spare tops one should le short, of stiff whalebone, for trolling near weeds and ledger fishing; another longer. and more pliant, for spinning a minnow and heary float fishing, for jack, perch, or barbel; and a third top and second joint, much lighter, for roach, dace, and gudgeon fishing. Some rods have winch fittings on the second joint, but these increase the weight of the rod, and an extra short butt is much to be preferred. If you have two rods, the light one had better be of cane, and the heavy one of hickory; both should, of course, have rings- the latter one, perhaps, small pieces of brass tube, as they obviate the chance of the line catching, as it sometimes will, round the rings in trolling. These brass pipes may be procured at any of the fishing-tackle shops. Whatever the rod 
is made of it should always have a free and equal spring in it from the butt end to the top. This is of the greatest importance when you are playing any large fish; therefore be particular always to have the rod that you may be buying put together first, and try it in your own hands. For an angler residing in the vicinity of the water which he is in the habit of fishing, a better rod for spinning cannot be obtained than by buying a long bamboo cane, which costs two shillings, splicing a piece of whalebone on the top, and fitting the cane with fixed rings. I think that the length of the rod depends much on fancy; the one I use for trolling, and fishing from the bank, is about fourteen feet, and this I alter to eleven feet for my punt rod: this rod, which is as good a one as can be made, cost two pounds ten shillings; but rods that will catch fish can be bought for four shillings and sixpence, or less; and it often happens in remote country districts, where the fish are not so highly edneated as they are in the Thames, that a straight hard stick will do quite as much mischicf as the rod that is brought to the water in the polisherd oak box and cost five pounds. An accident to a roul is a great nuisance to the angler, therefore be always provided with an extra top; a fracture in any other joint of the rod can generally be set with a piece of twine that has been rubbed with cobblers' wax (always to be carried in book). Next to the rod comes the reel, or winch, and when I have said that this adds much to the comfort of all fishing, and is almost a necessity, I have said enough. They are, of eourse, to be bought at all fishing-tackle shops, and vary in price from two shillings to almost any sum, depending on their elick and multiplying properties.

Following closely on the reel we have

\section{LINES.}

These are made of all sorts of material, depending upon the kind of angling they unay be required for: the running line for light fishing, such as roach, dace, gutgreon, de., should be of silk, or silk and hair: an old fly-line, whether tapering or not, answers the purpose well. T'hose composed of hair alone are very light, and do not hold the water like a silk line; this is, of course, a great advantage in fly fishing. Thirty yards will be enough on the reel, and this will only be wanted when a barbel is hooked, in roach fishing, or when a large perch takes the red worm 
meant for the gudgeon. For spinning and trolling, the line should be what is termed patent, (it is merely plaited silk prepared with a peculiar kind of varnish), and about fifty or sixty yards long. A very good substitute for the above varnish or dressing, as it is called, can be made in the following way:-Take a small phial and fill it two-thirds full with boiled oil, and the remaining third with gold size. Shake them well together, and it is ready for use : it should be applied with a piece of flannel, the line being passed through an inch of tobacco pipe; and then being exposed to the air, it will become quite dry. It may be used once or twice with this one coat of varnish on it, to make it smooth, and then it may have another coat, and it will be perfect; an occasional renewal of the dressing as it wears away will, of course, preserve it. For trolling and ledger fishing, the line should be rather stouter than for trout and perch fishing, and may, if the angler chooses, be fitted on a wooden reel (or pirn, as it is called in Scotland) of about four inches across, with a deep groove for the line. These reels turn with great rapidity when a cast is made, and are wound up quickly with the fore-finger.

On the end of the line, depending on what kind of fishing it is being used for, it is necessary to have

\section{TRACES AND BOTTOMS.}

The former, used for jack fishing, are of gimp, about a yard in length, and should have two steel swivels on them, and one or two leads (tapering at each end), depending on the strength of the stream, \&c. Those used for trout fishing are of gut, and are fitted in the same way; these are also of service in perch and barbel fishing, with a float, and in paternoster fishing.

Bottoms may be of hair or gut for roach, dace, and gudgeon fishing, and about four yards in length. I have found that those of twisted materials generally are not to be trusted: if the swim is a rapid one, or barbel and perch are in the locality, those of gut had better be used, as hair is so very likely to snap at the strike of a heavy fish.

Next in order we have

\section{HOOKS;}

but as these will all be spoken of in the description of catching each fish, any remarks here would be superfluous. Every 
angler should be able to bind on a hook; and for this purpose he has always in his book some cobblers' wax and silk.

We pass to

\section{FLOATS,}

which should, of course, be adapted to the water you are fishing in, and to the nature of your baits: if the stream be sharp, the float nust be calculated to carry a larger number of shot than if you were angling in still water, as otherwise it will be carried away in all directions, and the bait would not touch the bottom; but never use a heavier float than is really necessary, because the less shot you have on your line the better, for the less is it likely to be seen. The line should be shotted so as to leave only so much of the float out of water as to be just visible, particularly in roach fishing, as they bite cxtremely fine. The shot should not be large, and the last one should be placed about four inches from the hook. In live-bait fishing for pereh and jack, the float must of course be larger, whether there be stream or not, as the bait is apt to be pulled down. You need only weight it sufficiently to make it stand on the water, and a spinning lead or sunall roll plummet may he used instead of shot. The most pleasant float for general 'Thames fishing is that made of cork, with a porcupine's quill through it, with a small brass ring on the lower end, and a cap on the top: a half hitch of line under this top cap prevents the gut from slipping down, and thereby altering the depth, and it also keeps the float the same distance from the hook, should the cap come off or split, as is sometimes the case, and then you are eomplled to plumb again. There is a float called a Nottingham George, that regulates itself according to the depth of the stream; it is very useful in travelling for Barbel.

We lastly have

\section{B.ITS;}

and for the moment putting aside artificial flies, live-baits for jack and perch, and spinning and trolling baits, which will be mentioned under the chapters on 'Trout, Jack, and Perch, I begin with the worm. 'The largest of these, the lob or dew-worm, may be taken at night with the assistance of a lantern on any lawn or green where the grass is short, more particularly after a wet day; and if the weather is very hot and dry a number of pails of water may be thrown down during the afternoon, and these 
will much assist to bring the worms to the surface at night. Lob-worms may also be found by digging in a garden; but the former is the most wholesale way of taking them. They are five or six inches long, and are a good bait for large grayling, perch, bream, eels, and trout. 'The brandling worm is striped with yellow marks, and smells very strongly; it may be found in any old damp dung, and is a rery excellent bait for most kinds of fish. 'The red worm I prefer to all others as a general bait; it is of a bright red colour, and is smooth; it suits trout, roach, dace, perch, gudgeon, tench, carp, eels, and barbel, and indeed every kind of fish, and will be found to keep much better on the hook than the brandling. The marsh worm is found at the cdges of ponds, and can always be seen on pulling up the root of a flag; it answers the same purpose as the red worm, but it is not so tongh. All these varieties should be kept in a jar or flowerpot, in damp moss-they will then scour themselves and become bright, and after a few days much tougher; if they are to be kept for any long time some earth and dung should be added. The gentle is a universal bait; it may be bred most plentifully in the summer by hanging a piece of bullock's liver, scored with a knife, over a tub of red sand; this assists the gentles to scour and make themselves tough, so hard indeed will they get in this way, that they will remain a long time on the hook, if, unfortunately, they are not removed by a fish. Gentles may be kept for any time by being buried in a box in the earth ; great care should be taken not to let the box remain in the sun, or they will all turn into chrysalides. Gentles are an excellent bait for roach, dace, barbel, bream, and carp; and tront, perch, gudgeon, and eels will take them sometimes. Paste is a bait in great estimation by some, and is adapted for all purposes in which a gentle may be used; it is principally used in winter, and the stream shonld not be too rapid, or the paste will come off. It is made like common dough, and becomes tongh by being constantly pulled and kneaded: when the water is coloured a grain or two of vermillion may be mixed with the paste; it must always be quite fresh, as the fish will not even look at stale paste. The crumb of new bread worked abont in the hand makes a good bait; and old Cheshire cheese done in the same way is useful in chub and carp fishing: or the two may be mixed together,-proving that what is good for the angler is good for the fish. Greaves broken to pieces, with 
boiling water poured on them and then chopped fine, is an excellent bait for dace, chub, and barbel; the small leatherlooking white pieces should be picked out for baiting, and the refuse worked up with clay and bran for ground-bait. Salmon roe is considered an excellent bait by many for fish where gentles are used; I have, however, never had any good sport with it: the fishing-tackle shops all keep it in small pots. Of eaddis, cow-dung bobs, and the different kinds of grubs, slugs, and water-crickets I shall say nothing, as they are not baits of common use, but may be found serviceable for tront, chub, and dace when grentles are scarce. Cockchafers, grasshoppers, and bees, are good for chub in the summer; I much prefer the former, which is really a killing bait. Birds, mice, frogs, fe., are used in jack fishing when nothing else can be obtained, and the fish are on the feed; they may do in the Lake districts, but I don't believe a bit in them in the Thames.

Of-

\section{GROUND-BAITS}

I shall say but little here, as a minute description will be given of them when speaking of the different fish; they are made of clay, lob-worms, common gentles, bran, pollard, bread, greaves chopped very fine, grains, and mill-sweepings. Mr. Blakey, in his very good book on "Angling," berins a chapter on baiting the ground thus:- "Those who live near a river, and especially those whose premises adjoin it, should select an even bottom and a place moderately deep, and regularly feed the fish. Make everything convenient for the sport; put up a luurdle, if there be no bushes, and tuck evergreen branches between the bars; make it fast in the ground, rather leaning over the water. If there be an eddy, or scarcely any stream, you may liang up a liver or a dead eat on a sloping stick for want of a tree, so that the magrgots may drop from it in such a spot that they will get to the bottom about where you fish; or it is better to provide earrion gentles and worms, and bait the place exactly day after day. If there be a stream, make balls of clay, maggots, and worms, bread, greaves, snails, and any living things you can get, only use enough clay to sink them-in other words, make the ground-bait rich; when you are going to fish put the same quantity of bait, but make it poor, and you are as sure of sport as you wet your line. Whoever fishes a pond or river 
often should prepare a place; and the object of the hurdle is to place a complete screen between you and the fish, and it will be the fault of the angler if he is seen at all. Land your fish beyond the hurdle, on the side which is most handy. When you are on your own ground, if there be no holes or deep places, make one at any cost; and this is especially necessary in some ponds which are shallow at the edge. When there are many weeds, have them cleared, if possible, altogether. If no other way presents itself, use your drag, but it should be done days before you fish. Nake but a hole, or small deep, form a good screen, regularly feed the fish, and with good clean baits and appropriate tackle you will take some of the best in the water.'

With this I will end the chapter, and now take the different fish in order, and give the best ways for catching them, always remembering that this little book is on Thames Angling, and does not treat of the salmon, or of fly fishing, beyond the little bobbing that one gets under the willows, or on the scowers of the Thames anywhere, from the source of the river down to the towing-path under

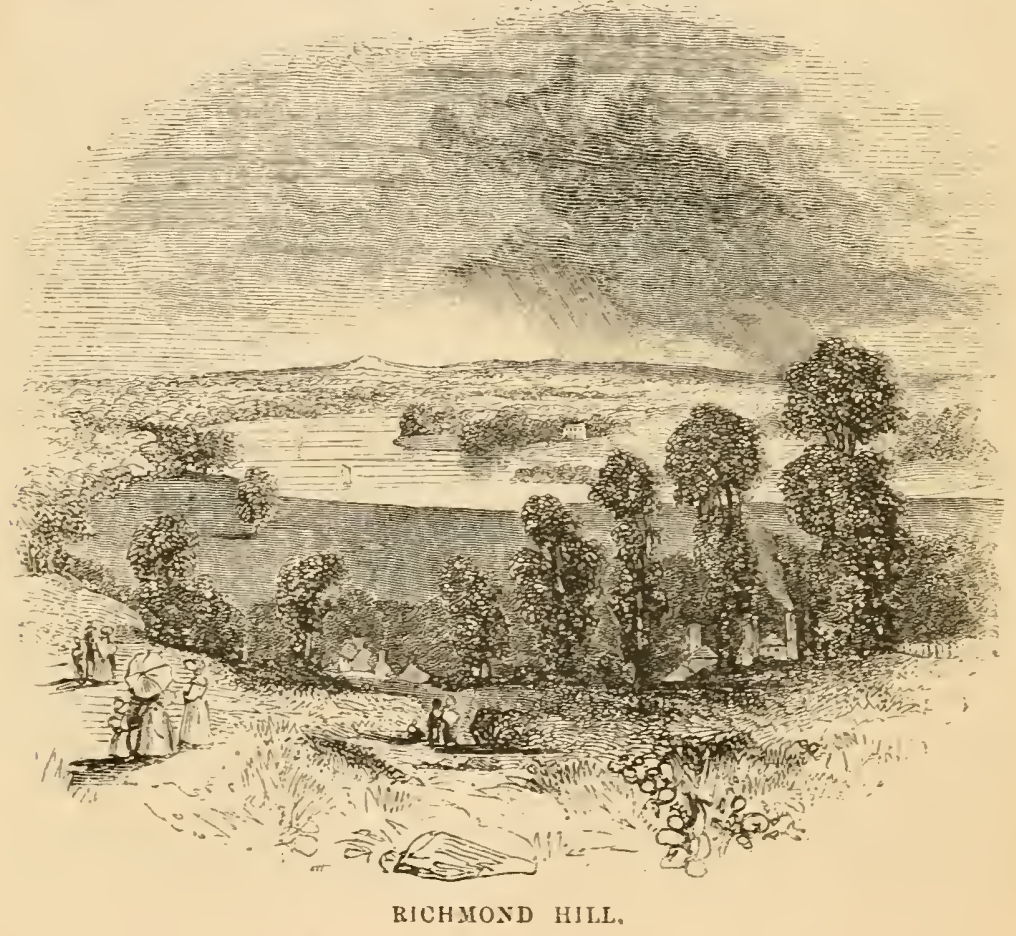




\section{CHAPTER IV.}

OF THE DIFFEREN'T DESCRIPTIONS OF FISH, AND THE MANNER OF ANGLING FOR EACH.

"With hurried steps

The anxious angler paces ou, nor looks aside, I est some brother of the angle, ere he arrire, Possess his favourite swim."

\section{THE TROUT.}

'THis splendid fish is the object of every true angler's ambition, and, in the 'Thames, fortunate indeed is he who, after a week's continual spinning, succeeds in making one of these beantiful

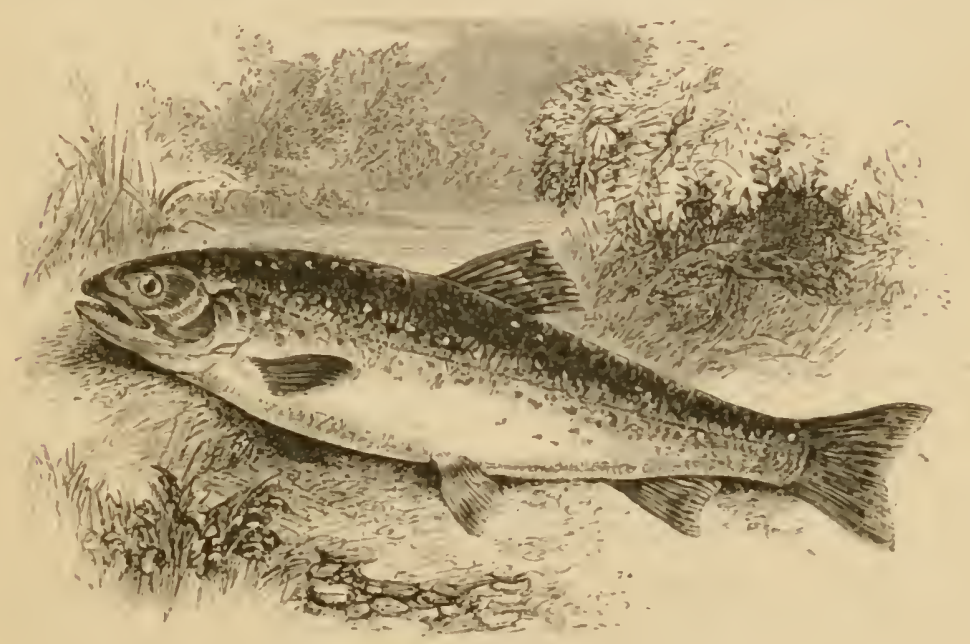

THF: TROUT.

specimens of the finny tribe his own-decidedly handsomer in this river than any other in England; where, I am glad to say, they are generally thought to be on the increase, owing 
in a great measure, I believe, to the exertions of the Thames Angling Preservation Society, which has been unremitting in its endeavours to put down poaching; and of which Society some account will be found towards the end of the book. 'The Trout varies very much in form, colour, and flavour, in different rivers, and sometimes even in the same piece of water varieties may be met with. They spawn about October and November, and come into season about April, being in perfection in May and June, and continuing so till September. All Trout have their haunts and homes, generally under a large stone, or trunk of a tree, especially at a mill-tail. Each fish has his regular run of water, and seldom goes into his neighbours' preserve; they will remain a long time in the same place. Mr. Blakey mentions one that never moved for ten weeks; he tried every bait, but could never get him to look at any one; soon a flood came and the fish departed. I remember, in 1852, a Trout under the centre arch of the bridge at Geneva; he was there for ten days, I left and travelled through Switzerland and Italy, and at the end of eight weeks, when I returned, I found him there still.

The Thames produces, I believe, the largest freshwater Trout in England, with the exception perhaps of the Driffield river; but the number of 'Trout in the Thames is so small, and the store of patience required so great, that $I$ am afraid I cannot recommend the beginner to expend much time in fishing for them; although the more initiated, and those residing on the spot, will be amply repaid for their perseverance, as one fish caught in a weir or sharp stream will afford glorious sport, and I doubt if even a professed salmon fisher would despise the efforts of one of our ten-pound 'Thames Trouts to regain his liberty. As an encouragement to those who require it, I need only refer them to the walls of some of the inms on the banks of the 'Thames from Teddington upwards.

Spinning commences about the beginning of April, but even earlier if the weather be warm. As I have before mentioned, nothing will be said of fly fishing, for although 'I'hames Tront are occasionally caught with a fly, this is of such rare occurrence, as to render any list of flies to be used for them perfectly useless. It may perhaps not be out of place here to observe that in the 'Thames, bottom fishing ecrmmences on the 1st of June, and lasts till the 1st of March; and during the other months, which 
are termed fence months, it is illegal to angle at the bottom, though, as I have said before, trout fishing commences earlier.

Before I proceed to give instructions for fishing with the minnow and bleak, I may as well quote Izaak Walton's method, which he adopted more than 200 years ago :-

"And then you are to know that your minnow must be put on your hook, that it must turn round when it is drawn against the stream; and that it may turn nimbly you must put it on a big-sized hook, as I shall now direct you, which is thus: put your hook in at the mouth, and out at the gill; then, having drawn your hook two or three inches beyond a-through his gill, put it again into his mouth, and the point and beard out at the tail; and then tie the hook and his tail about very neatly, with a white thread, which will make it the apter to turn quick in the water; that done, pull back that part of your line which was slack when you did put your hook into the minnow the second time. I say pull that part of your line back, so that it shall fasten the head, so that the body of the minnow shall be almost straight on your hook; this done, try how it will turn by drawing it across the water, or against the stream; and if it do not turn nimbly, then turn the tail a little to the right or left hand, and try again till it turn quick, for, if not, you are in danger to eatch nothing; for know that it is impossible that it should turn too quick."

I have described the rod and running line already: The bleak, gudgeon, or small dace, are the baits in most general use on the 'lhames, the minnow being more adapted to smaller streams. I shall content myself with giving my readers a description of the 'lackle generally employed on the 'Thames, and which may be purchased at any of the tackle shops, for about a shilling or eighteen pence.

The lionks should be Nos. 9 or 10, tied on a piece of gut about twelve inches long, with a loop at the end. 'The form is as follows:-Three hooks together at the end, then one tied on the reverse way, then three the same way as the first, and then one moveable on two small hair loops, in order to suit the size of the bait; the hooks, which arc placed at equal distances from each other, should, when the moveable hook is brought as near the others as possible, be about the length of a small gudgeon or bleak. 'i'he mode of putting on the bait is this:--. Insert one of the end hooks in the bait's tail, which must be slightly bent, and 
fixed in that position by putting the reversed hook in the side of the bait; the other hooks must then be fixed at such distances as not to bend the fish, and the sliding hook fastened into the lips of the bait, and kept in its position by a small shot placed between the bait's mouth and the binding of the hook.

Great care must be taken to keep the bait straight up to the bend in the tail, as otherwise it will not spin properly. A piece of gut, called a trace, described a few pages back, must be used, having two swivels, one in the middle and the other at the end; this is to be affixed to the loop of the gut on which the hooks are bound, and the whole then fastened to the running line by a loop at the other end of the trace. If any difficulty should be experienced in procuring baits, an artificial minnow, or a bait termed a kill-devil, or a spoon-bait, will be found a very good substitute, particularly when the water is at all coloured. Baits can be taken to the water placed in bran in a tin box; the instant they are pulled through the stream the bran leaves them, and they beconie perfectly clean and bright.

In spinning, the throws should be made rather across the stream, and when your line is ont, the point of the rod should be kept nearly at right angles with the line, which must be pulled in slowly, about a yard at a time, till the throw is repeated. In spinning from weirs, however, the line may be drawn in very slowly, as the violence of the stream will canse the bait to spin, and in general also will hook your fish; a smart stroke, however, to make sure, will do no harm. A small piece of round wood fixed on the end of the spinning or trolling rod, to prevent the pressure of the butt from hurting the chest or side, is a very desirable appendage to spinning tackle. Another very common mode of fishing for T'Trout, thongh not much practised on the 'Thames, is termed bush fishing. Your hook must be adapted to the size of the bait, which may be worms, cad-baits, grubs, beetles, grasshoppers, or natural flies. You should try to keep the top of the rod even with the edge of the water, for if the shadow of it is seen, the fish will start off at once. Fish without a float, with a short line, and sink your bait with a single shot. When the Trout is hooked, keep the line in a slanting direction, as it is easier to get him out of the water, and he does not so much disturb the hole.

Trout are much more often taken now with a fly in the 
Thames, than they used to be a few years since. In June, 1851, Mr. W. H. Russell was whipping for Chub and Dace from the bank that runs at the side of Walton Bridge, hook No. 8, fly green silk body, peacock tail, silver twist, red hackle, and starling wing feather wing: fish took the fly and rushed up stream, through the arch, and was nearly sawing the line on the edge of the pier. After a few minutes MIr. Russell succeeded in landing the fish, which proved to be a Trout of six pounds and three quarters. On the bank it disgorged a frog: from its mouth. It was a very fine thick fish, but more yellowish than usual, and its spots very clearly marlied.

'Trout are often taken in the 'Thames with a ledger', while barbel fishing, as are Perch, Eels, and sometimes large Dace.

During the last few years, some anglers have taken to spin down stream, instead of up and across; this is generally done

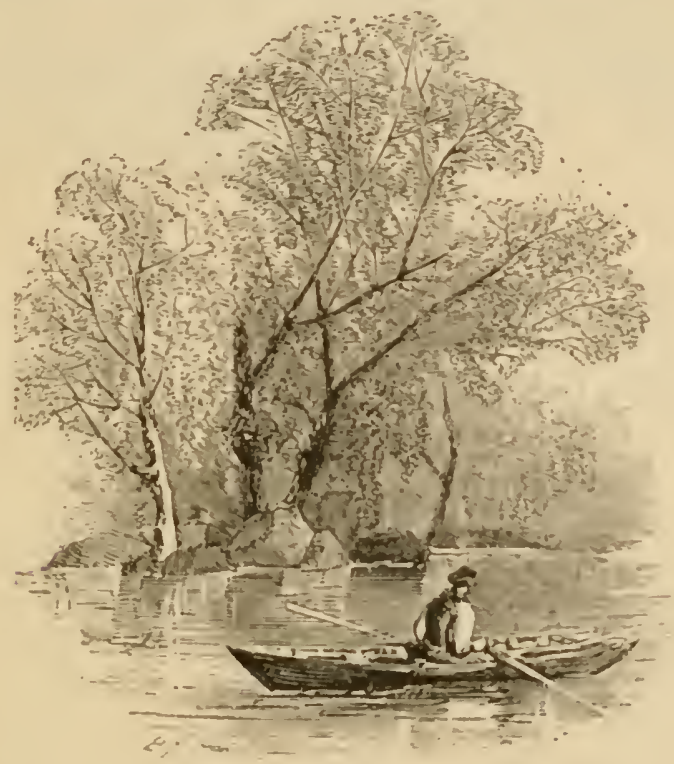

with another hand pulling a skiff gently down the stream; you can, however, work this way yourself, by letting your bait trail over the stern of the boat, with some twenty or thirty yards of line ont. I do not particularly recommend this plan, you get no exercise for the arms, and it is but little better than setting a trimmer for Jack. 


\section{THE PIKE OR JACK.}

The distinction between the above two appellations is, that a Jack becomes a Pike when it weighs 3 lbs. The Pike is a most unpleasant neighbour to all other fish whose misfortune it is to be smaller than himself, save the Perch and 'Tench: the former

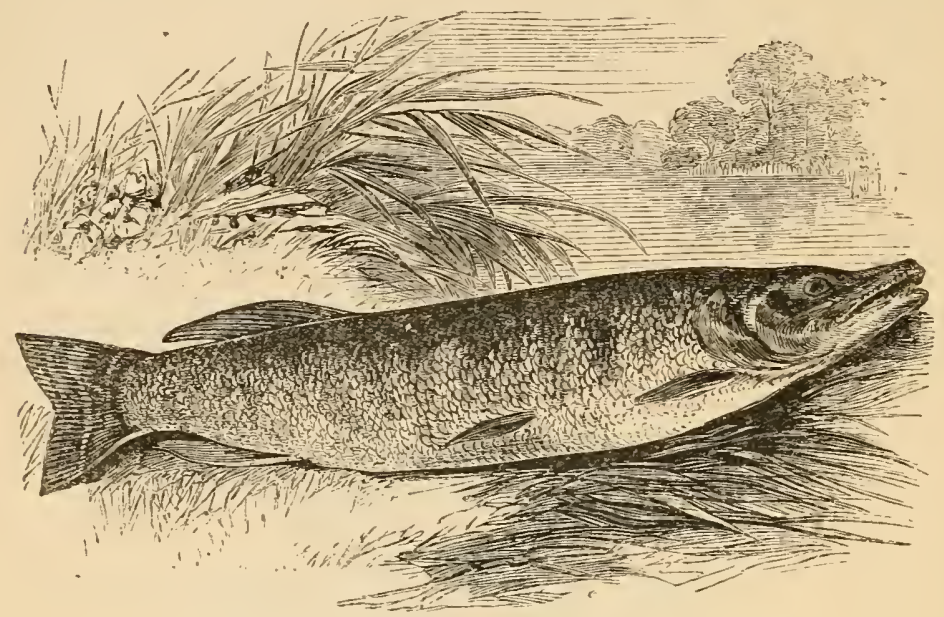

THE PIKE.

because even the ferocity of the Pike cannot stomach the array of sharp points on the back of the Perch; and the latter because, as it is said, the Pike is aware of the 'Tench's medicinal properties, and is loath, therefore, to attack the family physician. Pike spawn in April, generally in ditches at the sides of the water they inhabit: and when the food and water are favourable, this fish grows very fast. 'They are in season from May to the end of February, or beginning of March ; the best time, however, for Pike fishing is, in my opinion, from October to January. The Pike is decidedly the most voracious of all the freshwater tribe; and many are the anecdotes related of his boldness when excited by hunger. I have caught one weighing only $4 \mathrm{lbs}$. with the remains of another of his own species, of abont $1 \mathrm{lb}$., half gorged in his throat. I have had the same fish come at the bait three times after he had been hooked and torn himself away.

These fish grow to an immense size, and in all the tishing books stories may be found of their attacks on ducks, geese, swans, and even eagles. I was at the catching of a Pike by Mr. 
Mr. IT. Hallett, at Littleton, that weighed $28 \mathrm{lbs}$; and last year Mr. Richard Arabin brought me one to look at, that he had caught near Christchurch, that weighed 40 lbs., the largest I ever saw.

Pike fishing in the Thames commences about Teddington, and sport may be met with from thence up to Strectly. There are two modes of angling for this fish-namely, with a live bait, or with trolling tackle; and, as a general rule, I should recommend the former method in small pieces of water, or where there is much weed, and the latter in large open places. Whatever tackle be used must always be of gimp, in consequence of the sharp teeth with which the Pike is armed, and which enable him to bite gut in two, as all anglers have often had sad experience of, when angling for Tront or Perch. I have found great benefit from binding the hook round with fine wire, as after catching a few fish the silk of the hook will be found ent through.

For live-bait fishing (if not in a punt), you should be provided with a kettle of gudgeon, with a few roach and dace, a heavy rod and line (already described), a No. 3, 4, or $\tilde{5}$ hook on a piece of gimp, and fastened to the reel line with a swirel. and a float having, for convenience' sake, a hole down the middle, throngh which the rmming line is put, and fastened with a wooden peg, this float being more convenient for jack and perch fishing than that in common use. It must be large enough to prevent the bait from sinking it, and may be weighted either with shot, or a sinall piece of slieet lead. 'The object of the swivel is to permit the bait to swim round the line (which it will always do) without turning the float. 'The bait may either be hooked through the lip, in which case, when there is a run, you must allow the fish to go as far as he will, and gorge the bait, taking great care not to check lim; or the hook nay he inserted under the back fin, and you will then strike at once, as the Pike always takes a fish across, and turns it round head first to gorge. The former mode is perferable when the fish are on the feed, as the bait lives longer ; but the latter should be adopted when the fish only play with the hait. 'There is another kind of hook which is termed a snap, and is composed of two spring hooks confined in a wire frame, with a smaller one to insert in the back fin of the bait; the large hooks in striking a fish escape from their confinement and expand : this is the surest way of killing fish, but will be too large and showy in clear water. It is baited by introducing the point of the small hook under 
the skin of the bait, on the side, and bringing it out at the back fin. There is a third kind of live-bait hook composed of two hooks placed back to back, and having a much smaller one bound on the gimp just at the end of

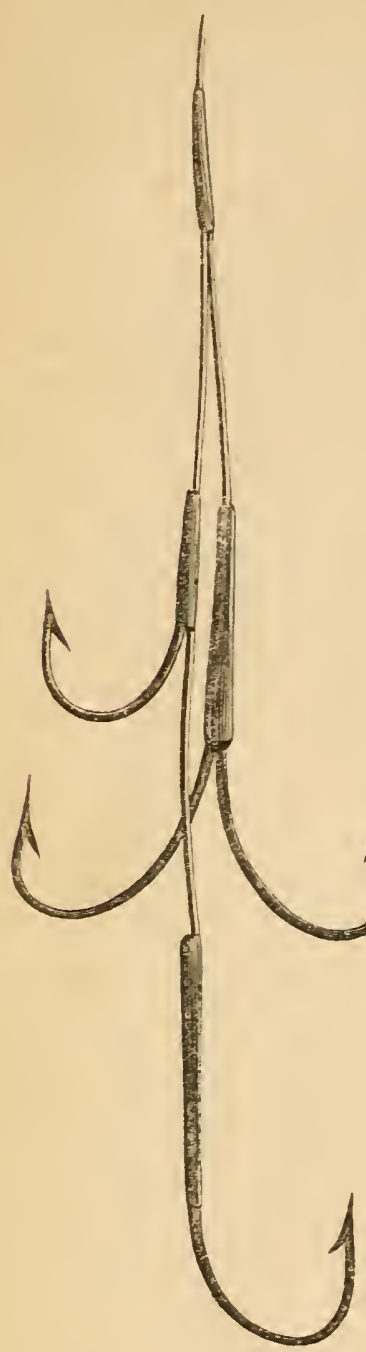
their shanks. The bait is put on this upper small hook as on the snap, and the two larger hooks hang down at the side of it. When fishing with this hook, you can strike much quicker than when using the lip hook.

When I am fishing with a live bait, I very much prefer a set of hooks peculiar to myself, for I never'saw them in any fishing-tackle shop. They somewhat resemble the one described above, but differ from it in two points : first, the hook for the back fin of the live-bait has a little more play; and there is an additional large hook, which hangs on the opposite side to the large pair of hooks. Descriptions of this kind are not very clear, so I have made a little drawing of the tackle. In my sets of hooks I find that the binding at the top extends a little lower down the two pieces of gimp than in the engraving.

Trolling is practised either with the gorge, or with tackle of the same description as that already described in spinning for Trout, merely substituting gimp for gut, and using rather larger hooks. This is my farourite mode of Pike fishing, and is, I think, far preferable to the gorge, particularly when the-fish are not well on the feed. Or with the spoon-bait, an invention of the last few years, which has deservedly met with the greatest success: they can be purchased at any of the fishing-tackle shops, with or without their hooks and traces; they are used for spinning and trolling, and are a good bait for Trout, Jack, and Perch. The gorge is a double hook on twisted brass- 
YA 01286 


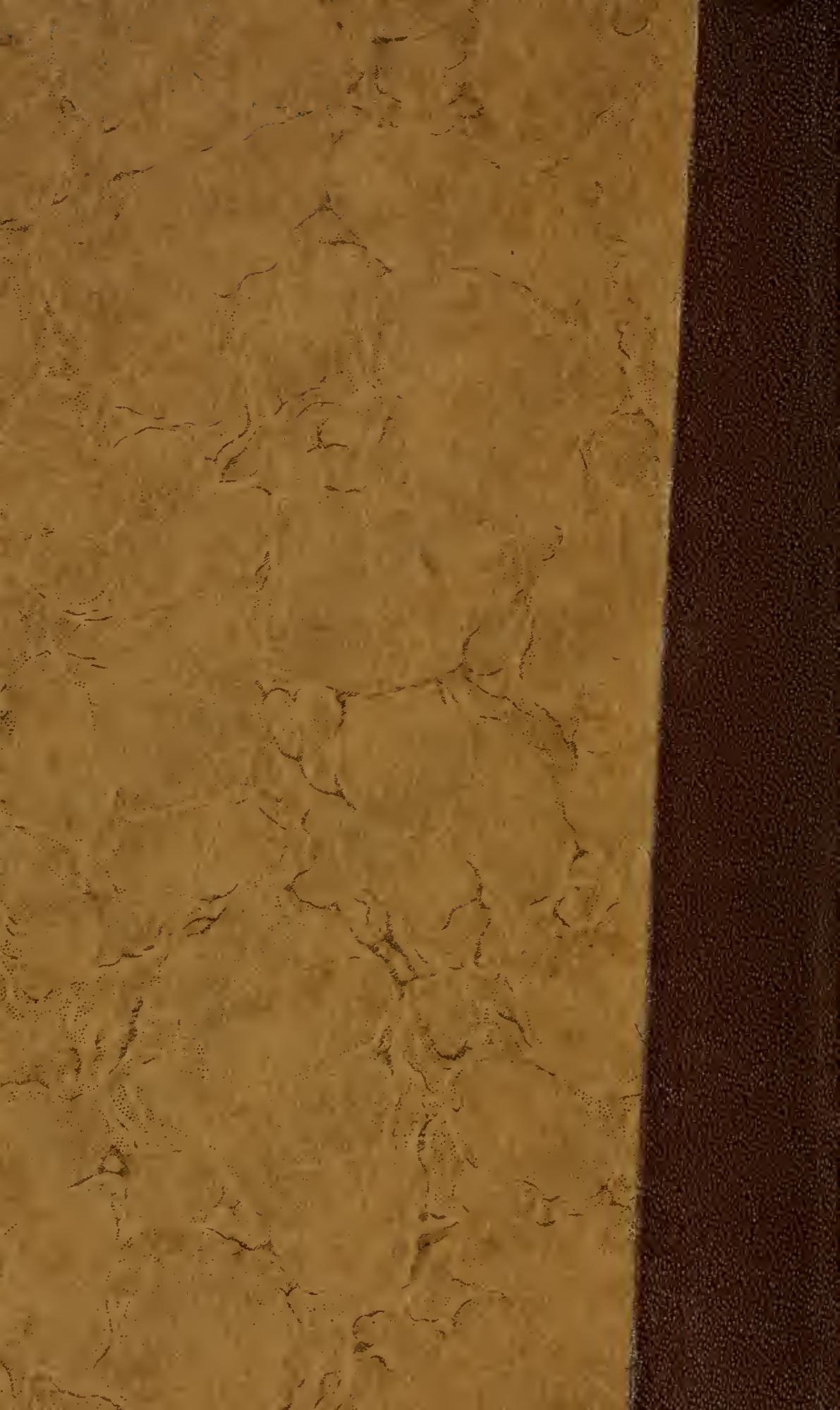

